\title{
Глицин в кормлении цыплят-бройлеров и применение кристаллического глицина с целью снижения уровня сырого протеина в рационах
}

\author{
Абашкина Е.М., соискатель (аспирант) \\ ФГБНУ Федеральный научный центр «Всероссийский научно-исследовательский и технологический институт птицеводства» \\ Российской академии наук (ФНЦ «ВНИТИП» РАН)
}

\begin{abstract}
Аннотащия: Настоящий обзор посвящен бопросу изучения потребностей цыплят-бройлеров б добабках аминокислоты глицин. Необходимый уровень и качество протеина, то есть аминокислотный состав рациона, имеет важнейшее значение для поддержания продуктибности и здоровья жиботных. Применение кристаллических аминокислот при снижении общего уровня сырого протеина 6 рационах для бройлеров давало эффектибное снижение экскреции азота. При добаблении к таким рационам сбободного глицина во многих экспериментах отмечалось повышение эффрективности усбоения азота и продуктивности бройлеров. Глицин ябляется незаменимой аминокислотой для иьллят и рассматривается как один из бажнейших факторов бозможности экономии протеина 6 кормах для бройлеров при сохранении их здоровья и бысокой продуктибности, что важно и для экономической составляющей птицеводства. Включение синтетического глицина, учет и нормирование глицин-экбивалента $\mathcal{B}$ рационах с пониженным уровнем сырого протеина улучшают продуктибность и здоровье птицы, а также снижают риски экологических проблем птицебодстба.
\end{abstract}

Ключебые слова: протеин, аминокислоты, глицин, серин, глицин-эквивалент, продуктивность бройлеров.

\section{Значение глицина в обме-} не веществ и в рационах цыплят-бройлеров. Глицин является заменимой аминокислотой для взрослой птицы, но незаменимой или частично незаменимой для молодняка, так как синтезируется в его организме в недостаточном количестве. Заменимые аминокислоты поступают в организм с кормами, а также частично могут синтезироваться из других соединений в ходе промежуточного обмена.

Хотя у птиц глицин синтезируется в организме, в рационе должно быть обеспечено 40\% от общей потребности в этой аминокислоте, поскольку ее синтез может быть недостаточным для синтеза белка и удовлетворения потребностей, связанных с другими метаболическими процессами, особенно на фоне высоких эндогенных потерь [1].
Протеиногенные аминокислоты глицин и серин в организме птицы взаимосвязаны и выполняют разнообразные и очень важные функции, участвуют в синтезе многих биологически важных соединений.

В первичной структуре белка каждая третья аминокислота - это глицин. Много глицина и серина в кератине, этот белок необходим птице для формирования тканей перьев, клюва и когтей. Наиболее богаты глицином белки коллаген и эластин. Глицин участвует в образовании креатина, желчных кислот, в синтезе холина, гемоглобина, способствует снижению токсичности других аминокислот и продуктов обмена веществ.

Важна роль глицина как компонента мочевой кислоты, и считается, что именно это является одной из основных функций, об- уславливающих незаменимость этой аминокислоты в кормлении домашней птицы. Другие функции глицина, не связанные с синтезом белков, включают в себя то, что он является предшественником ряда биологически активных молекул: глутатиона, оснований нуклеиновых кислот, гема, креатина, желчных кислот, наряду с метаболизмом метильной группы [2]. Многогранность функций глицина создает высокую потребность организма молодняка птицы в глицине и делает его незаменимой аминокислотой в период старта и роста, когда его эндогенный синтез недостаточен.

Дополнительный глицин может быть необходим для поддержания максимальной продуктивности цыплят-бройлеров в возрасте от 21 до 35 дней жизни, когда они питаются рационами 
на основе исключительно растительных ингредиентов и с низким содержанием сырого протеина (СП). Глицин может прямо или косвенно влиять на правильную функцию слизистой оболочки кишечника и улучшать использование энергии рациона [2].

Роль глицина в обмене веществ изучается и в человеческой медицине, так как глицин - основной компонент коллагена и эластина, структурных белков кожи и всех связок, сухожилий, суставов, сосудов и многих других органов, где присутствует соединительная ткань.

«Коллаген - это белок, характеризующий животный мир, так как это материал, который обеспечивает многоклеточную гибкость. Коллаген возник с происхождением животного мира в докембрийском взрыве и является самым распространенным белком в организме человека, составляя более четверти общего белка. Высокое содержание глицина в коллагене (одна треть аминокислотных остатков) подразумевает важное требование доступности этой аминокислоты для поддержания здорового обмена коллагена, достаточно высокого, чтобы избежать проблем накопления нежелательных химических модификаций, поскольку белково-дефицитная диета вызывает снижение оборота белка, особенно коллагена» - отмечается в работе [3].

Глицин обладает огромным потенциалом для улучшения здоровья, роста и благополучия как людей, так и животных [4].

Уровни сырого протеина и аминокислот в кормах. Качество и уровень протеина в рационе имеют важнейшее значение для поддержания здоровья и продуктивности животных. Однако высокий уровень протеина
В кормах создает проблемы для окружающей среды и постоянную потребность для птицеводов в высокобелковом сырье. С другой стороны, высокий уровень СП в рационе вреден и для организма самого животного, поскольку вызывает нарушения обмена веществ и ухудшение здоровья. В кормлении домашней птицы В современных условиях предпочтительно использование рационов с пониженным содержанием СП, что позволяет снизить стоимость кормов и общий объем потерь азота с пометом.

Выделение азота в окружающую среду может быть эффективно снижено при уменьшении концентрации СП в корме. Эксперименты, однако, показали, что корм, содержащий менее 1920\% СП, часто оказывал нежелательные эффекты на продуктивность цыплят-бройлеров в возрасте 1-21 дней [5].

Использование кристаллических аминокислот при снижении уровня СП в рационах для бройлеров показало эффективное снижение экскреции азота. В то же время, скорость и эффективность роста были ниже у бройлеров, которых кормили рационом со снижением СП более чем на 3\%, даже когда все известные требования по питательности были удовлетворены [6].

В экспериментах при добавлении к таким рационам свободного глицина регистрировалось повышение продуктивности бройлеров.

Известно, что многие аминокислоты при избыточном скармливании могут оказывать токсическое действие. Например, уровни треонина, превышающие рекомендуемое значение, отрицательно сказывались на показателях роста, когда потребность в СП удовлетворялась на 100\%. Сооб- щалось также, что избыток треонина снижал потребление корма бройлерами и скорость их роста. Избыточные или несбалансированные аминокислоты корма расщепляются до углеводородных остатков и аммиака, который, будучи очень токсичным для живых клеток, превращается организмом птиц в мочевую кислоту [7].

Исследования эффективности добавок глицина в рационах бройлеров. Было замечено, что глицин улучшает производительность цыплят-бройлеров. Так, еще в 1955 г. сообщали, что дополнительный глицин необходим для поддержания оптимального роста и эфффективности кормления быстрорастущих цыплят. Позднее также указывали, что рост, эффективность кормления и удержание азота улучшаются с добавлением глицина в рацион.

Результаты опыта, проведенного В 2005 г., показали, что предпочтительнее поддерживать в кормах более высокий уровень глицина, чем рекомендуется NRC (1994), когда уровень СП в рационе снижается. Значительный эффект от добавок глицина в рационы с низким уровнем СП может быть обусловлен его ролью в образовании мочевой кислоты [8].

В настоящее время исследования, в основном, направлены на улучшение использования рационов с пониженным уровнем СП для цыплят-бройлеров, с использованием добавок свободных кристаллических аминокислот, как по отдельности, так и в различных сочетаниях, например с треонином, серусодержащими аминокислотами, другими заменимыми аминокислотами. Тематика экспериментов с использованием глицина достаточно обширна; в них изучали влияние его добавок не только на показатели продуктивности птицы, 
но и другие параметры: характеристики тушки, использование питательных веществ растущими цыплятами, развитие и проницаемость слизистой оболочки кишечника, экспрессия генов отдельных белков, концентрация мочевой кислоты в плазме крови, показатели воспалительной реакции у цыплят-бройлеров, показатели крови и иммунные реакции растущих бройлеров, экскреция азота, качество помета, снижение частоты пододерматитов и др.

Так, в эксперименте по изучению влиянию добавки глицина на показатели воспалительного ответа у бройлеров были получены результаты, которые свидетельствуют о том, что обеспечение глицина выше уровней, рекомендуемых для роста, снижает воспалительный ответ и связанную с ним задержку роста цыплят, наблюдаемую в ответ на системное заражение [9].

В опыте 2018 г., изучая влияние рационов с низкими уровнями СП $(16,3 ; 14,7$ и 13,2\%) и 4 концентрациями глицинового эквивалента (ГЭ) на рост цыплятбройлеров, характеристики экскреции азота, а также вариации метаболома плазмы крови, отметили, что минимальный уровень, до которого может быть снижен СП в рационе цыплят-бройлеров без ухудшения роста, и требуемая для этого концентрация ГЭ неизвестны. В этом эксперименте было показано, что при уровне СП ниже 15\% уже другие вещества, помимо ГЭ и незаменимых аминокислот, могут быть лимитирующими и ограничивать эффективность использования азота корма и продуктивность птицы [10]. Исследования в данном направлении продолжаются.

Снижение уровня СП в рационе бройлеров выгодно для удешевления рациона, уменьше- ния выделений азота, выбросов аммиака и частоты возникновения пододерматитов, что было изучено в ряде экспериментов. Тем не менее, исследования показали, что снижение содержания СП в рационе более чем на 2,0\% может привести к неоптимальным показателям прироста массы тела и коэффициента конверсии корма у цыплят-бройлеров $[5,11]$. Стратегии смягчения неблагоприятных показателей роста бройлеров включали добавление солей калия, включение глютамина или аспарагина в качестве источника азота и увеличение энергии в рационе. Однако эти подходы дали противоречивые результаты. Дальнейшие исследования показали, что помимо удовлетворения потребностей В незаменимых аминокислотах, бройлерам может потребоваться минимально-необходимая концентрация глицина+серина в составе рациона для достижения показателей роста, аналогичных тем, которые дают бройлеры на рационах с высоким содержанием СП [6].

Сообщалось, что добавление глицина повышает усвояемость липидов в рационе кур-несушек из-за возможного эмульгирующего эффекта, связанного с ролью глицина в синтезе желчных солей, способствуя, таким образом, действию ферментов поджелудочной железы на жиры и их всасыванию в стенке кишечника. Следовательно, добавление глицина может улучшить усвояемость кормовых жиров и увеличить содержание обменной энергии в рационе бройлеров. Однако эта роль глицина мало изучена у цыплят-бройлеров [12].

Сообщалось, что изменение содержания в рационе СП и аминокислот может повлиять на барьер- ную функцию кишечника. Были проведены эксперименты на цыплятах-бройлерах для оценки влияния добавления L-глутамина, глицина и L-аргинина в рацион с пониженным содержанием СП [13].

Поскольку глицин для цыплят в стартовый период считается незаменимой и первой лимитирующей аминокислотой из разряда заменимых, большинство исследований проводилось именно на цыплятах до 21-дневного возраста. Лишь в ограниченном числе исследований оценивали рост и выход мяса у цыплятбройлеров, получавших рацион со сниженным содержанием СП и изменяющимся содержанием суммы глицин+серин после стартового периода. Кроме того, неясно было, с чем именно связаны положительные реакции показателей роста бройлеров при добавлении глицина к рационам с пониженным содержанием протеина, вызваны ли они потребностью в глицине как таковой или вкладом азота. Поэтому был проведен эксперимент по определению влияния кормления рационами с пониженным содержанием СП, дополненными глицином и/или L-глютамином (источником азота), на показатели роста и характеристики тушек бройлеров в течение 41-дневного периода выращивания. Общим выводом по результатам этого опыта было то, что глицин оказывает более выраженное влияние на поддержание оптимального прироста массы тела и конверсию корма у цыплят-бройлеров, чем добавка азота, а также то, что общая масса и выход мяса грудки не отличались, при обеспечении адекватной общей концентрации глицина+серина и азота, несмотря на снижение содержания СП 
в рационе на 2,4\% в течение всего периода выращивания [11].

В другом эксперименте было отмечено снижение потребления воды и повышение эффективности использования азота при снижении СП и добавлении глицина в рационы на основе пшеницы [15].

Проблема нормирования глицина или глицин-эквивалента в кормах для бройле-

ров. Большинство экспериментов, изучающих влияние добавок глицина, проводилось на кукурузно-соевых рационах, и даже при этом однозначного мнения о необходимом уровне глицина или ГЭ в кормах до сих пор нет. Это связано с тем, что глицин вездесущий компонент организма, взаимосвязан в процессе метаболизма с очень большим количеством биологически активных веществ, и влияние на его потребность - многофакторное.

При удовлетворении потребности птиц в метионине и цистеине потребность птицы в глицине может снижаться, так как часть серина идет на синтез эндогенного глицина.

Треонин может функционировать как предшественник глицина, поскольку непосредственно метаболизируется в глицин с помощью фермента треонин-альдолазы, с ацетальдегидом в качестве побочного продукта. Холин также может превращаться в глицин в присутствии L-гомоцистеина, и следует учитывать уровни холина в рационе бройлеров, так как увеличение содержания холина в рационе снижает потребность в суммарном количестве глицина+серина.

При снижении уровня СП в рационе уровни глицина+серина тоже резко снижаются. Следовательно, возможно, что предель- ные уровни глицина+серина в рационе становятся причиной снижения продуктивности бройлеров при уменьшении СП более чем на $3 \%$. Было показано, что добавки глицина способствуют полному восстановлению продуктивности птицы в стартерном периоде с низким содержанием СП в кормах [6,12]; однако, это не было подтверждено у птиц в период роста (21-35 дни жизни). Потребность в глицине во время фаз роста и финиша изучалась мало; это периоды, в течение которых добавки глицина могут быть важны для максимизации продуктивности у птицы, получающей рационы с низким содержанием СП, составленные без включения сырья животного происхождения. Содержание глицина и серина в растительном сырье - невысокое, наиболее богатые источники этих аминокислот - мясная, рыбная и перьевая мука. Однако в силу определенных причин это сырье в промышленном птицеводстве на сегодняшний день используется редко и в небольшом количестве.

На основании данных, полученных в ряде исследований, можно утверждать, что включение свободного глицина и серина в рацион с уровнем сырого протеина 156 г/кг может улучшать продуктивность птицы [14]. Установлено, что сочетание добавок глицина, L-глютамина, L-пролина, L-аланина и L-аспарагина в рационе на основе кукурузы и соевого шрота с низким уровнем СП (16\%) восстановило показатели роста бройлеров в возрасте от 1 до 18 дней до уровня тех групп, которые получали рацион с более высоким содержанием СП (22\%). Однако когда эти заменимые аминокислоты добавлялись в рацион с 16\% СП индивидуально, глицин был единственной заме- нимой аминокислотой, которая смогла обеспечить такое улучшение роста бройлеров $[6,11]$.

В организме основной источник глицина - это серин (аминокислотный путь синтеза). Серин является предшественником глицина - в результате потери 1 $\beta$-атома углерода в его боковой цепи, а глицин превращается в серин путем добавления 1 углеродного звена. Таким образом, пищевая взаимосвязь делает необходимым совместное рассмотрение потребностей в этих двух аминокислотах [12].

Животные могут конвертировать глицин в серин и наоборот. Поэтому было предложено рассчитывать показатель ГЭ как сумму количества глицина и молярного глицин-эквивалента серина [6]. Составление корма с использованием ГЭ более целесообразно, чем использование общей суммы глицин+серин. Вычисленный для кормового сырья ГЭ может применяться как любая другая отдельная аминокислота в составе корма.

Кроме этого, на реакцию бройлеров при добавлении глицина в рацион влияют как его предшественники, так и метаболиты, которые зависят от глицина, включая треонин, общие серусодержащие аминокислоты и холин. Адекватное обеспечение рационов этими питательными веществами может ограничивать реакцию на введение в них дополнительного глицина [1 1].

Дозозависимое исследование, проведенное на рационах с использованием пшеницы, позволило сделать вывод, что уровни усвояемого глицина+серина в низкобелковых диетах 12,4 г/кг и 11,4 г/кг в фазе роста и финиша, соответственно, являются достаточными. Кроме того, можно сни- 
зить содержание СП в рационе ростового и финишного периода на 30 г/кг при условии, что аминокислотный баланс и уровень в рационе соответствуют требованиям птицы путем добавления свободных аминокислот. Таким образом, уровень включения соевого шрота может быть снижен на 46\% [15].

В исследовании, направленном на изучение реакции бройлеров на поддержание адекватного уровня глицина+серина в рационах периода с 8- до 42-дневного возраста с низким уровнем СП путем добавления глицина, было установлено, что поддержание уровня глицина+серина 2,32\% с помощью обогащения глицином позволило снизить СП на 4,5\% без ухудшения показателей прироста и качества тушек бройлеров. При этом данный прием не смог полностью преодолеть депрессию показателей роста у бройлеров, получавших рацион с снижением СП на 6\% [16].

Заключение. Снижение уровня СП в рационах мясной птицы становится актуальным фактором оптимизации птицеводства и дает много положительных эффректов. Отдельные аминокислоты из линейки заменимых при снижении СП в кормах более чем на $3 \%$ становятся лимитирующими, и их нормирование будет в ближайшем будущем актуальной проблемой в кормлении, особенно это касается глицина и серина, учитывая их роль в обмене веществ и влияние на продуктивность птицы, иммунный статус и здоровье бройлеров. Актуальность учета и регулирования этих аминокислот обусловлена также тем, что растительное сырье, из которого формируют современные рационы в птицеводстве, содержит небольшое количество глицина и серина - в 2,5-3 раза меньше, чем в мясной или рыбной муке.

Рекомендации по кормлению разных кроссов птицы на сегодняшний день не дают конкретных уровней глицина или гЭ в рационах, и вопрос оптимизации рецептов кормов для птицы, с учетом снижения уровня СП и обеспеченности организма цыплят-бройлеров глицином, пока остается открытым и требует дальнейшего изучения. Поскольку не определены четкие уровни этих аминокислот в рационах цыплят-бройлеров, то исследования необходимо продолжать в плане определения оптимальных соотношений ГЭ с лизином, серусодержащими аминокислотами и треонином, согласно концепции идеального протеина, а также с учетом уровня холина. Возможно, такие исследования дадут основу для выработки алгоритма улучшения питательности кормов для каждого периода выращивания цыплят-бройлеров при снижении уровня СП от принятых на сегодняшний день рекомендаций, а также позволят в значительной степени защитить природу от агрессивного воздействия выбросов азота.

\section{Литература}

1. Kriseldi, R. Effects of glycine and glutamine supplementation to reduced crude protein diets on growth performance and carcass characteristics of male broilers during a 41-day production period / R. Kriseldi, P.B. Tillman, Z. Jiang, W.A. Dozier III // J. Appl. Poult. Res. - 2017 - V. 26. - P.558-572. 2. Powell, S. Effects of glycine supplementation at varying levels of methionine and cystine on the growth performance of broilers fed reduced crude protein diets / S. Powell, T.D. Bidner, L.L. Southern // Poult. Sci. - 2009. V. 88. - P. 1407-1412.
3. Melendez-Hevia, E. A weak link in metabolism: the metabolic capacity for glycine biosynthesis does not satisfy the need for collagen synthesis / E. Melendez-Hevia, P. de Paz-Lugo, A. Cornish-Bowden, M. Luz Cardenas // J. Biosci. - 2009. - V. 34. - P. 853-872.

4. Razak, M.A. Multifarious beneficial effect of nonessential amino acid, glycine: A review / M.A. Razak, P.S. Begum, B. Viswanath, S. Rajagopal // Oxid. Med. Cell. Longev. - 2017: 1716701. 5. Siegert, W. Relevance of glycine in crude protein-reduced broiler nutrition / W. Siegert, M. Rodehutscord // LOHMANN Information. - 2017. - V. 51, No 2. - P. 10-16.

6. Dean, D.W. Glycine supplementation to low protein, amino acid-supplemented diets supports optimal performance of broiler chicks / D.W. Dean, T.D. Bidner, L.L. Southern // Poult. Sci. - 2006. - V. 85. - P. 288-296.

7. Sigolo, S. Effect of a low crude protein diet supplemented with different levels of threonine on growth performance, carcass traits, blood parameters, and immune responses of growing broilers / S. Sigolo, Z. Zohrabi, A. GalIo, A. Seidavi, A. Prandini // Poult. Sci. 2017. - V. 96. - P. 2751-2760.

8. Jiang, Q., Improving the utilization of diets low in crude protein for broiler chicken. 1. Evaluation of special amino acid supplementation to diets low in crude protein / Q. Jiang, P.W. Waldroup, C.A. Fritts // Intl J. Poult. Sci. - 2005. V. 4, No 3. - P.115-122.

9. Takahashi, K. Dietary supplementation of glycine modulates inflammatory response indicators in broiler chickens / K. Takahashi, A. Aoki, T. Takimoto, Y. Akiba // Br. J. Nutr. - 2008. V. 100. - P. 1019-1028.

10. Hofmann, P. Very low crude protein and varying glycine concentrations in the diet affect growth performance, characteristics of nitrogen excretion, and the blood metabolome of broiler chickens / P. Hofmann, W. Siegert, Á. Kenéz, V.D. Naranjo, M. Rodehutscord // J. Nutr. - 2019. - V. 149, No 7. - P. $1122-1132$. 
11. Kriseldi, R. Effects of feeding reduced crude protein diets on growth performance, nitrogen excretion, and plasma uric acid concentration of broiler chicks during the starter period / R. Kriseldi, P.B. Tillman, Z. Jiang, W.A. Dozier III // Poult. Sci. - 2018. V. 97. - P. 1614-1626.

12. Ospina-Rojas, I.C. Commercially available amino acid supplementation of low-protein diets for broiler chickens with different ratios of digestible glycine+serine:lysine / I.C. Ospina-Rojas, A.E. Murakami, C. Eyng, R.V. Nunes, C.R.A. Duarte, M. D. Vargas // Poult. Sci. 2012. - V. 91, No 12. - P. 3148-3155.

13. Barekatain, R. Performance, intestinal permeability, and gene expression of selected tight junction proteins in broiler chickens fed reduced protein diets supplemented with arginine, glutamine, and glycine subjected to a leaky gut model / R. Barekatain, P.V. Chrystal, G.S. Howarth, C.J. McLaughlan, S. Gilani, G.S. Nattrass // Poult. Sci. 2019. - V. 98, No 12. - P. 6761-6771.

14. Chrystal, P.V. Effects of reduced crude protein levels, dietary electrolyte balance, and energy density on the performance of broiler chickens offered maize-based diets with evaluations of starch, protein, and amino acid metabolism / P.V. Chrystal, A.F. Moss, A. Khoddami, V.D. Naranjo, P.H. Selle, S.Y. Liu // Poult. Sci. -2020. - V. 99, No 3. - P. 1421-143.
15. Van Harn, J. Effect of low protein diets supplemented with free amino acids on growth performance, slaughter yield, litter quality, and footpad lesions of male broilers / J. van Harn, M.A. Dijkslag, M.M. van Krimpen // Poult. Sci. - 2019. - V. 98. - P. 48684877.

16. Wang, W. Response of broilers to gradual dietary protein reduction with or without an adequate glycine plus serine level / W. Wang, J. Wang, S. Wu, H. Zhang, G. Qi // Ital. J. Anim. Sci. 2020. - V. 19, No 1. - P. 127-136.

\section{Для контакта с автором:}

Абашкина Елена Михайловна

E-mail: e.abashkina@kormovit.ru

\title{
The Role of Glycine in Diets for Broilers and the Possibility of the Reduction of Dietary Crude Protein Level by Glycine Supplementation
}

\author{
Abashkina E.M. \\ Federal Scientific Center "All-Russian Research and Technological Institute of Poultry" \\ of Russian Academy of Sciences
}

\begin{abstract}
Summary: The requirements of broiler chicks in glycine and the advantages of the supplementation of diets with glycine are reviewed. The level and quality (amino acid profile) of dietary crude protein (CP) is extremely important for health and productivity. The supplementation of diets with different synthetic amino acids allows the reductions of total CP level and nitrogen excretion with feces. Glycine can be regarded as essential amino acid for growing chicks; its dietary concentrations can be also calculated in units of glycine equivalent (with the interconversions of glycine and serine taken into account). In many experiments the supplementation of low-CP diets with free glycin resulted in the improvements in nitrogen assimilation and productive performance in broilers. Therefore, the additional supplementation of diets with glycine can allow for the saving on the expensive dietary protein sources, maintain health and productivity in broilers fed low-CP diets, and reduce the excretion ma nitrogen to the environment, thereby improving the economical and ecological sustainability of broiler production.
\end{abstract}

Keywords: crude protein, amino acids, glycine, serine, glycine equivalent, productive performance in broilers.

ОТРАСЛЕВЫЕ НОВОСТИ

\section{КНР проверит экспортеров РФ по Видео}

Из-за коронабируса Китай въел новое требование для российских жиботноводов, экспортирующих продукиию 6 Поднебесную. Речь о проведении видеоинспекиий забодов с 2022 года. Об этом страна уже убедомила Россельхознадзор. До этого момента Китай бизуально не проверял отечественные предприятия.

Как проводить видеоинспекцию, 6 отрасли пока не понимают. Например, неясно, сколько должна длиться проберка и что конкретно китайцы должны посмотреть. Поэтому компании готовят сбои предложения по единому алгоритму, которые Россельхознадзор позже сможет обсудить с китайской стороной. Закон $6 \mathrm{cmynит} 6$ силу с 1 янВаря 2022 года. Документ предусматривает, что Китай допустит произбодителя 6 страну после проверки главного таможенного упрабления $\mathcal{G}$ очной форме или $\mathcal{6}$ режиме бидеоинспекции. Предюдущий приказ КнР не содержал таких требований. 